\title{
Productivity of Festuca rubra L. -Agrostis capillaris L. Grasslands
}

\author{
Ioan ROTAR ${ }^{1 *}$, Mirela CIREBEA ${ }^{1}$, Roxana VIDICAN ${ }^{1}$, Florin PĂCURAR ${ }^{1}$, Anamaria MĂLINAŞ ${ }^{1}$ and Ovidiu \\ RANTA $^{1}$ \\ ${ }^{1}$ Department of Plant Culture, Faculty of Agricultural Sciences, University of Agriculture Sciences and \\ Veterinary Medicine Cluj-Napoca, România \\ *Corresponding author: rotarioan52@yahoo.fr
}

Bulletin USAMV series Agriculture 72(2)/2015

Print ISSN 1843-5246; Electronic ISSN 1843-5386

DOI 10.15835/buasvmcn-agr: 11565

\begin{abstract}
European countries has changed and are focus on increasing productivity that prevailed during the early and middle twentieth century has now widened to incorporate environmental concerns. Today all concerns are related to the adaptation strategies to climate change on grassland. The replacement of nitrogen fertilizer with nitrogen derived from $\mathrm{N}_{2}$ fixation offers important economic and environmental advantages. Therefore, we need more productivity systems but all have to be in the same time "friendly with environment". This is the reason why our experiment tries to determine the productivity of mountain grasslands and find answer equally scientific and practical for next generation. The experiment was placed after experimental technique method and includes six different fertilized treatments in four replications on mountain grasslands. Experiment is establish in Baisoara Commune, Cluj County. The experience includes four variants in three repetitions, which are: V1 - control variant, (unfertilized); V2 - variant fertilizer with $10 \mathrm{t} /$ ha manure; V3 - variant fertilizer with $10 \mathrm{t} /$ ha manure + 50N25P25K; V4 - variant fertilizer $20 \mathrm{t} /$ ha manure; V5-variant fertilizer with $10 \mathrm{t} /$ ha manure + 100N50P50K and V6-variant fertilized with $100 \mathrm{~N} 50 \mathrm{P} 50 \mathrm{~K}$. After a short time period there are statistical assurances in treatments which are fertilized with high organic or mineral inputs. Large quantity of fertilizer improve productivity of grasslands.
\end{abstract}

Keywords: productivity, fertilization, grasslands, mountains.

\section{INTRODUCTION}

For high-yielding dairy cows dietary crude protein requirements are assumed to range between 14 and 18\% (Pacheco and Waghorn, 2008). Nitrogen yield increased linearly before reaching a plateau at an $\mathrm{N}$ input of 350 to over 400 kg N ha-1 (Herrmann et al, 2014).

The addition of $\mathrm{N}$-fertilizers not only stimulates growth of plants, but also increases the potential of direct N2O losses (Sturite et al, 2014). No interaction between $\mathrm{K}$ and $\mathrm{N}$ application was found on the DM yield, but there was an interaction effect on the K content of the grass (Holshof et al., 2014).
Since legislation imposes restrictions on the use of mineral nitrogen-based fertilizers, traditional organic fertilizers (such is cattle manure) are being applied and are now becoming a significant factor for achievement required forage production (Simić et al, 2014). Fertilizer treatments affected yield, especially in the first cut: the yield was doubled by fertilization, in comparison with the control treatment (Simić et al, 2014).

\section{MATERIALS AND METHODS}

The experiment was established in 2014in the place "Cross", in Băişoara Commune, Apuseni 
Mountains, Romania on a Festuca rubra L. - Agrostis capillaris L. grasslands type, at the altitude of 1240 $\mathrm{m}$. It was delimited experimental field to remove any unwanted danger or grazing has been cleaned of woody vegetation and rocks. The experience was placed after experimental technique method. The surface of experimental plots is $20 \mathrm{~m} 2$. The experience includes four variants in three repetitions, which are: V1 - control variant, (unfertilized); V2 - variant fertilizer with $10 \mathrm{t} /$ ha manure; V3 - variant fertilizer with $10 \mathrm{t} / \mathrm{ha}$ manure + 50N25P25K; V4 - variant fertilizer 20 t/ha manure; V5-variant fertilizer with 10 t/ha manure $+100 \mathrm{~N} 50 \mathrm{P} 50 \mathrm{~K}$ and V6-variant fertilized with $100 \mathrm{~N} 50 \mathrm{P} 50 \mathrm{~K}$.

Floristic studies were performed before mowing after scale vegetation interpretation given by Braun-Blanquet (1932). Cattle and horse manure and also the mineral inputs were applied in early springtime on the plots (in the beginning of March), according to the treatments.

\section{RESULTS AND DISCUSSION}

Like were expected, the mineral fertilization has the highest value compare to control. The combined fertilization have a good productivity compare to the treatments fertilized with organic manure (Tab.1). Variants fertilized with high quantity of fertilizer (V3, V4, V5 and V6) present statistical assurance compare to the control variant (V1). Nitrogen is a key factor in grassland farming and in ruminant nutrition and through the provision of feed from grasslands these two compartments are closely related (Isselstein and Kayser, 2014). In general, to increase the protein yield from grassland you have to increase nitrogen fertilization or fostering the growth of forage legumes (i.e. grass-clover systems, Isselstein and Kayser, 2014).

Even if we put $20 \mathrm{t} / \mathrm{ha}$ manure (V4) this variant present only $2.12 \%$ compare to the control. An explanation of this could be that time period is too short and organic manure did not have time to decompose. This affirmation is based on other studies made by Rotar, 2005, who show that on grassland fertilizers applied on vegetation cover which reason cannot incorporate, leading to a delay in action, especially in the case of less soluble.

A same result obtain Pavlu et al, 2012, when show that a continuous long-term application of nitrogen $(\mathrm{N})$ phosphorus $(\mathrm{P})$ and potassium $(\mathrm{K})$ fertilisers increases stand productivity and nutrient content in soil and forage but substantially reduces plant species richness.

Compare with control variants, all fertilized variants present an increase of harvest (Tab. 2). Variants fertilized with 20 t/ha manure (V4) compared with variants with $10 \mathrm{t} /$ ha manure (V2) present only $1.20 \%$ an increased harvest. If we compared the variant with $20 \mathrm{t} / \mathrm{ha}$ manure with variants V3 and V6 we can noticed a difference of $1.64 \%$.

Variants fertilized only with mineral fertilizer 100N50P0K (V6) compared with variants fertilized with $20 \mathrm{t}$ /ha manure (V4) increase only with $0.44 \%$. Similar data obtained Morea (2008) on a Festuca rubra L grassland type, in Gîrda de Sus village, where she show that the application $100 \mathrm{~N} 50 \mathrm{P} 50 \mathrm{~K}$ brings a quantity of harvest of 5.55 t/ha dry matter, a difference from the natural pastures of $2.13 \mathrm{t} / \mathrm{ha}$ dry matter, very close in value to that obtained from the application

Tab. 1. Influence of fertilization on dry matter yield in 2015 (t/ha)

\begin{tabular}{ccccc}
\hline Dosing of fertilization & Yield (t/ha) & Percent \% & Differences t/ha & Significance \\
\hline V1- 0 kg/ha & 2,31 & 100,0 & 0,00 & Mt. \\
V2- 10 t/ha manure & 3,22 & 139,7 & 0,92 & - \\
V3- 10 t/ha manure + 50N25P25K & 4,86 & 210,8 & 2,56 & $* * *$ \\
V4- 20 t/ha manure & 4,42 & 191,8 & 2,12 & $* * *$ \\
V5-10 t/ha manure + 100N50P50K & 4,78 & 207,2 & 2,47 & $* * *$ \\
V6-100N50P50K & 4,86 & 210,8 & 2,56 & $* * *$ \\
\hline DL (p 5\%) & & & 0,96 & \\
\hline DL (p 1\%) & & 1,33 & \\
\hline DL (p 0.1\%) &
\end{tabular}


Tab. 2. The yield differences among variants and their significance (2015)

\begin{tabular}{ccccccc}
\hline \multirow{2}{*}{ Variants in ascending order } & 1 & 2 & 3 & 4 & 5 & 6 \\
\hline & - & 3,22 & 4,86 & 4,42 & 4,78 & 4,86 \\
\hline F1 & 2,31 & 0,91 & 2,55 & 2,11 & 2,47 & 2,55 \\
\hline F2 & 3,22 & 1,64 & 1,20 & 1,56 & 1,64 \\
\hline F4 F5 & 4,42 & & 0,00 & 0,36 & 0,44 \\
\hline F6 & 4,78 & & & 0,00 & 0,08 \\
\hline F3 & 4,86 & & & & & 0,00 \\
\hline SX average error & 4,86 & & & & & \\
\hline Variants & 0,32 & 3,01 & 3,16 & 3,25 & 3,31 & 3,36 \\
\hline Values q & & 0,96 & 1,01 & 1,04 & & \\
\hline Teoretical DS values & & & & & & \\
\hline
\end{tabular}

of $150 \mathrm{~N} 75 \mathrm{P} 75 \mathrm{~K}$ namely $5.58 \mathrm{t}$ /ha dry matter difference of $2.15 \mathrm{t}$ /ha compared to the control.

\section{CONCLUSION}

All treatments present differences when were compared to the control. Applied fertilizer produces changes in productivity. Long-term application of NPK fertilizers increases plant productivity and soil nutrient concentrations and this can result in the dominance of largely speciespoor grasslands with little conservation value.

The grass yield was influenced mainly by mineral-nitrogen fertilizers.

\section{REFERENCES}

1. Herrmann A., Techow A., Kluß C. and Taube F. (2014). Plant or animal needs - how to determine the optimal $\mathrm{N}$ intensity of grassland? Grassland Science in Europe, Vol. 19 - EGF at 50: the Future of European Grasslands, 535537.

2. Holshof G. and van Middelkoop J.C. (2014) Towards a new potassium fertilization recommendation in the Netherlands, Grassland Science in Europe, Vol. 19 - EGF at 50: the Future of European Grasslands, 245-247.

3. Isselstein J. and Kayser M. (2014). Functions of grassland and their potential in delivering ecosystem services.
Grassland Science in Europe, Vol. 19 - EGF at 50: the Future of European Grasslands, 199-214.

4. Morea Adriana (2008). Cercetări asupra evoluției biodivrsității și productivității în pajiștile de Festuca rubra din etajul boreal (cu privire specială asupra Munților Apuseni). Teză de doctorat -USAMV Cluj- Napoca.

5. Pacheco D. and Waghorn G.C. (2008) Dietary nitrogen - definitions, digestion, excretion and consequences of excess for grazing ruminants. Proceedings of the New Zealand Grassland Association 70, 107-116.

6. Păcurar F. and Rotar I. (2014). Metode de studiu şi interpretare a vegetației pajiştilor. Risoprint Publisher,Cluj-Napoca, Romania, 225.

7. Pavlu Vilem, Jan Gaisler, Lenka Pavlu, Michal Hejcman and Vendula Ludvikova. 2012. Effect of fertilizer application and abandonment on plant species composition of Festuca rubra grasslands. Acta Oecologica 45; 42-49.

8. Rotar I. și Carlier L. (2005). Cultura Pajiștilor, Ed. Risoprint, Cluj-Napoca ,Cod ISBN 973-656-8112-1

9. Simić A., Rakić, V., Marković, J., Dželetović Ž. and Živanović (2014). Effect of manure enriched with clinoptilolite on pasture yield and quality. Grassland Science in Europe, Vol. 19 - EGF at 50: the Future of European Grasslands, 291-293.

10. Sturite I., Rivedal S. and Dörsch P. (2014) Effects of fertilization and soil compaction on nitrous oxide (N20) emissions in grassland. Grassland Science in Europe, Vol. 19 - EGF at 50: the Future of European Grasslands, 94-96. 